\title{
Ukraine and Its Future in a Globalised International Community
}

\author{
Taras Melnyk
}

Ph.D. Student, Pereiaslav-Khmelnytskyi Hryhorii Skovoroda State Pedagogical University (Pereiaslav-Khmelnytskyi, Ukraine)

E-mail: taras.m.standard@gmail.com

https://orcid.org/0000-0001-9429-4035

The political and economic vector of Ukraine's development has changed many times over the years of independence. Contrary to rational economic institutional transformations, the society faced the slowdown of social progress and slogans of populism. Furthermore, the desire to get high results without making significant efforts tended only to sow chaos, confusion and dissatisfaction among the population.

The paper presents the author's vision of the further development and formation of the Ukrainian state, the patterns in which external and internal factors can influence these processes. The article also analysed a number of features inherent in modern-day Ukraine.

Keywords: Ukraine; state; economy; reforms; political vector; formation; future; development prospects

Received: October 12, 2018; accepted: November 5, 2018

Ukrainian Policymaker, Volume 3, 2018: 17-28.

https://doi.org/10.29202/up/3/3

\section{Introduction}

Every day Ukraine faces new political, economic, educational, social and cultural challenges before every new state. The accelerated development pace of the modern civilised world forces to react immediately to all circumstances, both internal and external, thereby shaping the national doctrine for decades.

The great differences in world inequality are evident to everyone, even to those in poor countries, though many lack access to television or the Internet [Acemoglu \& Robinson, 2012]. They are the result of a deliberate or unconscious choice of states, each of which faces the consequences of their own expressions of will and political steps. In the globalised world of the beginning of the third millennium, there is no rational justification for the backwardness of countries. One can surely state that as there is no country that has steadily moved through its institutional formation.

(C) Melnyk, Taras, 2018 
Therefore, after a thorough analysis of a number of political and economic decisions that should be considered the cornerstone in building a domestic political and economic paradigm, one can outline the prospects of the Ukrainian state in the future and its place in the international globalised community.

\section{Country's Potential}

Ukraine with an area of 603.7 thousand $\mathrm{km}^{2}$ is the largest country in Europe. Moreover, one should consider that $100 \%$ of the country is located on the European continent [Pestushko et al., 2016].

Natural resources of Ukraine include land, climatic, recreational resources, flora and fauna, resources of the Black and Azov seas, mineral deposits, internal waters, etc. The forest area is 8.6 million hectares: by their means, Ukraine meets $25 \%$ of its wood needs. The area of agricultural land is 41.8 million hectares (out of which 33.2 million hectares are arable land). The main types of soils include the following ones: alfisols, forest soils, chernozem, soddypodzolic soils, and brown earth [Malysh, 2013].

According to the report of the State Service of Geology and Mineral Resources of Ukraine, with regard to proven stocks of coal, iron and manganese ores, titanium, zirconium, kaolin, graphite, sulphate-potassium and sodium salts, facing decorative stones, our state is among the leading countries of the world, and in the European subcontinent, takes the first position in most of the corresponding rankings. Ukraine ranks first in the reserves of manganese ores and germanium among the member countries of the Commonwealth of Independent States, it also ranks second in coal, iron ores, and a number of rare metals.

Very high resource potential in deposits of gold, a number of non-ferrous metals (lead, zinc, copper, molybdenum), rare metals (beryllium, lithium, tantalum, niobium, scandium), and rare earth metals (yttrium and lanthanides). For most of them, Ukraine is able to take a leading position in Europe in the near future. According to the nominal estimate of the raw material base for rare metals, Ukraine ranks second among the representatives of CIS [Report, 2017e].

Ukraine belongs to the number of states of the world with reserves of all types of fuel and energy raw materials (oil, natural gas, coal, peat, uranium, etc.), and despite the high degree of the availability of this reserves, Ukraine provides itself with own energy resources only for about $47 \%$ [Report, 2017d].

It may seem that Ukraine obviously has all the necessary resource potential for attracting foreign capital, developing agriculture, having its own competitive production at the expense of cheap labour, and appearing in prominent positions in all possible international ratings. However, the potential is not always embodied in real growth indicators. The Gross Domestic Product per capita is considered to be one of the most accurate ways to assess the level of economic development of the state. The last 2017 Report on Index of Economic Freedom, published by the Heritage Foundation, contains the data on GDP per capita (purchasing power parity). In 2017, this indicator in Ukraine was $\$ 2,205$, compared with the leading countries of the world, the gross domestic product of Ukraine is significantly behind and places our country at $133^{\text {rd }}$ position among the 187 countries of the world for which the study was conducted [Report, 2017a].

At the same time, for example, Papua New Guinea is a country, which an average European knows only because it has a dozen active volcanoes, and it has a GDP per capita of 2,094.85 
US dollars. Moreover, tiny Luxembourg, a state 7 times smaller than the overall area of Rivne region, has a near-overwhelming figure of $\$ 108,004.9$, therefore heading this rating. What is the reason for this uneven development of countries?

\section{Economic Institutions}

Countries differ in their economic success because of their different institutional approach. Economic institutions are the study object of economic institutionalism; they can be inclusive and extractive. Inclusive economic institutions are those that allow and encourage participation by the great mass of people in economic activities, while extractive economic institutions are designed to extract incomes and wealth from one subset of society to benefit a different subset (elites) [Acemoglu \& Robinson, 2012]. Ukraine is among those countries that have built its own economic paradigm on the basis of extractive institutions. We can outline the following characteristic features of the extractive approach in the economic institutions of Ukraine:

1. The level of corruption in the country. According to the 2017 World Transparency International Corruption Perception Index, Ukraine ranked $137^{\text {th }}$. The index is graded from 0 (very high level of corruption) to 100 (very low level of corruption). According to it, Ukraine has improved its result for one point last year and received 30 points out of 100 possible. Iran and Sierra Leone received the same number of points [Report, 2017g].

Corruption is the eternal stumbling point of most states. After all, the possibility of obtaining undue advantage allows the officials to ignore the requirements of the current legislation and the norms of public morality easily. This trend, in turn, leads to the fact that most power and money are in the hands of a narrow circle of people, thereby leading to poverty and extremely low social welfare of the rest of population. In Ukraine, corruption reaches phenomenal scales. Beginning with the crisis of the 1990 s, corruption and comprehensive raiding (illegal takeovers) have become not only an annoying reality but also an integral part of the mentality of citizens and their outlook. Unfortunately, the impossibility of understanding the change of the existing system due to the lack of proper education, as well as the lack of legal counteraction instruments, eliminates any attempt to combat bribery, even at the ideological level. In fact, by creating a closed corrupt circle, the inhabitants of the country find themselves in a desperate state: they have either to join corruption for the sake of survival and self-realization, or to be on the fringes of society all the time. In the latter case, they would have to fight constantly for the observance of elementary human rights, and spend all their lives on judicial delusions or proclaiming ineffective manifestos as single outbursts of hope. The public hierarchy in a corrupt state, as a rule, is built on the basis of social injustice, the retention of people in fear, unjustified restrictions in a number of rights and freedoms. The investment climate in Ukraine is unfavourable, multinational corporations are flatly refusing to invest their own capital here.

2. Poor number of middle class representatives. According to preliminary estimates of the experts from the Razumkov Centre and the Institute for Demography and Social Research of the National Academy of Sciences of Ukraine, the middle class in Ukraine is no more than $14 \%$ of the population (according to Pew Research Center Report, in the United States this figure is $52 \%$ ) [Report, 2018b]. However, that taking into account the real purchasing power of the population, this figure may appear to be much lower [Libanova et al., 2014]. Although the issue of the middle class relevance in different countries of the world is one of the most controversial in the economy, since, in this case, it is worthwhile to distinguish between the "inner middle class" and the "middle class, tied to the conversion into foreign currency." 
According to Dmytro Vasilyuk, the middle class in society should perform the following roles [Vasilyuk, 2015]:

1. The national ideologist and facilitator of the statehood idea, the foundations of civil society and its own high moral behaviour;

2. Generator of innovation in the community with limited resources for economic development; actualisation of enormous intellectual and labour reserves;

3. Motivator of the development of the environment with the urgent need for import substitution, the effectiveness of the use of the endogenous potential of the economy to prevent the massive migration and demographic losses.

Even the high incomes of citizens should not be associated with the economic independence inherent to middle class. After all, after converting incomes into foreign currency, the middle class will be much less prosperous. Still, the middle class is primarily a population that can afford to travel and rest sometimes, buy quality household appliances and own a car. Furthermore, given the new possibilities for issuing visas to Ukrainian citizens for short-term trips to the European Union, shopping online, as well as the possibility to work remotely in foreign organisations, the relevance of measuring earnings in Ukrainian hryvnia is steadily declining as a real valuable indicator. Economic independence, first and foremost, is determined by the stability of the economic and political situation in the country, the accuracy of forecasting the level of inflation. Nevertheless, due to the existence of a number of opaque corruption schemes and excessive taxation of self-employed people, there is no need to talk about the possibility of economic independence.

Concerning the participation of the middle class in public life, both at the municipal level and in the country as a whole, it is rather an exception than a common practice. Only a few people are ready to engage in creating an ideological resistance movement, which will soon become a springboard for further institutional changes, after they realize the scale of the challenges they would have to face in the conditions of intellectual poverty of the nation. It should be noted that domestic representatives of the intellectuals and "brain" of the nation writers, engineers, and scientists, artists, and media professionals - prefer to work abroad, participating in massive labour migration. They are looking for decent living conditions abroad and payment for their own talents, thus investing in the development of other countries alien to them. Only officially, according to the data of the State Customs Service Report, in 2017 more than 7,325 Ukrainian citizens issued documents for permanent residence abroad [Report, $2017 \mathrm{c}]$. Even though there is no accurate statistics available, basically, we talk about thousands of talented professionals, whose own country was unable to offer a worthy future. The scant share of the middle class in society is also due to the fact that its existence is disadvantageous to the narrow circle of the ruling elite. After all, the middle class in theory has enough economic and intellectual power to destroy the existing system, so it is fairly viewed as a potential threat.

3. Lack of creative destruction. Scholars view creative destruction as a constant transformation of the country's economy in accordance with the most modern challenges of globalisation. In simple words, this is a change of old things and processes, irrelevant to the existing era of innovation, to the more favourable ones for the creation and development of the economic potential of the state. For example, the transition from traditional agricultural-artisan to industrial society at the end of the $17^{\text {th }}$ and early $19^{\text {th }}$ centuries in Western Europe is a vivid example of creative destruction in the economy, as it is a combination of time requirements with the development of advanced technologies and the patenting of a number of inventions that have changed the perception of the world forever. Moreover, if in the previous epochs 
of mankind existence creative destruction could last for decades or even centuries, today scientific and technological breakthroughs are occurring almost every day.

Creative destruction as a phenomenon is impossible in the presence of extractive economic institutions. Economic transformation can leave behind the enrichment of people who, because of their own ignorance and the reluctance to change society for the better, are incapable of keeping up with the times, offering ineffective reforms. In the conditions of creative destruction, a number of activities, professions, and equipment may simply become useless. So, for example, being the owner of a plant for the production of obsolete equipment — will you be happy to know that tomorrow there will be no demand for your products on the market? Surely, no.

Artificial inhibition of scientific and technological progress in Ukraine is one of the signs of the existence of extractive economic institutions. The Legatum Prosperity Index study 2017 conducted by the British non-profit organisation Legatum confirms it. The Report states that out of 149 surveyed countries, Ukraine ranked $112^{\text {th }}$ [Report, 2017b]. The index determines the level of progress with such criteria as economic growth, investment attractiveness, level of health care, pollution of the environment. It is rather difficult to believe that during the globalisation era, the state is unable to keep pace with progress solely because of the lack of knowledge or technology — both can be borrowed in the absence of own research and development outcomes. Furthermore, the modern propagation of consumerism makes transnational corporations look for new markets for their own technologies in order to increase capitalisation and strengthen the dominant position in the market segment. Simultaneously, the creation of a number of regional development programmes, availability of grant projects of the European Union partially solve the problem of lack of funds - searching for beneficiaries interested in investing in promising markets of developing countries is generally widespread practice.

The essential component of economic development is the proper level of education and science in the country. Actualisation of advanced professional knowledge in all branches is an integral part of improving existing market mechanisms.

With regard to school education, it is difficult to objectively assess the situation because Ukraine will only join the Programme for International Student Assessment (PISA) this year. The concept of the New Ukrainian School, which prerequisite is the adoption of the new Law of Ukraine "On Education" in September 2017, is quite promising. An attempt to modernise and improve the Ukrainian educational tradition by providing more autonomy to schools and the introduction of 12 years of schooling can become the basis for the modification of the entire existing educational sector, since students will be able to get the specialised secondary education in grades 10-12. Having received profile knowledge at school, students will more often choose vocational education, minimising the shortage of specialists in the technical professions in the labour market.

Higher education has a wider basis for analysis. According to the Report of the State Statistics Service of Ukraine for 2017/2018, there are 661 functioning higher education institutions in the country: 372 of them have I-II accreditation levels and 289 have III-IV accreditation levels respectively [Report, 2017f]. It would seem that the more educational institutions, the better, because as a matter of logic education in this case becomes accessible, significantly raising the level of awareness and professional competence among the population. However, according to the Times World University Rankings-2018, published in the international analytical educational weekly newspaper Times Higher Education, only one Ukrainian higher education 
institution was in the first thousand (Taras Shevchenko National University ranks between 801 and 1000 positions). In order to compare, there are 9 universities from the Republic of Poland and 12 from Czech Republic in the first thousand [Report, 2018c]. The Data Points Analytical Toolkit of this rating, in addition to published feedback and surveys of more than 200,000 scholars and students, examines the level of productivity of peers from different institutions at the local, regional and international educational levels. Accordingly, the given data testify to the low level of prestige of domestic higher educational institutions, the inability to meet the educational requirements of the $21^{\text {st }}$ century in the context of globalisation.

The educational approach in the vast majority of domestic higher education institutions is based on the concept of teaching, rather than developing students' ability to study, resulting in graduates failing to reach self-fulfilment in modern realities of high-tech information environment. Besides, the curricula is formed with excessive theorising of the study process, without taking into account the labour market situation. This leads to the lack of competitiveness of Ukrainian young professionals both in the country and abroad. In fact, going through the outdated materials during the study, the student, in the first place, must rely solely on his/ her own motivation and devote the lion's share of free time self-education, rectifying the innovations of European professionals.

According to the data of the Explanatory Note to the Draft Law of Ukraine "On Amendments to Section VI "Final and Transitional Provisions" of the Budget Code of Ukraine for 2017", R\&D/GDP intensity in Ukraine (or the State Budget expenditures for scientific research) is UAH $4,840.050$ million, or approximately $0.18 \%$ of the total GDP [Explanatory Note, 2018]. Despite the scarcity of funding, these funds are mostly for the maintenance of research institutions, not for the research itself. Objectively, a state that spends on science and research less than $1 \%$ of GDP cannot be considered developed, since the likelihood of creative destruction becomes limited, and the possibility of modernising any processes at the national level does not actually exist at all. Modern technological equipment and software are highly valued, and given that it is manufactured mostly abroad, the supply price becomes higher and higher. We should not forget about the proper level of wages of scientists, who, above all, should have enough motivation to work on long-term researches, spending weeks and months for the analysis of the received data. The level of remuneration of employees of educational institutions in Ukraine is much lower than in the EU member states and not only. As stated in the Resolution of the Verkhovna Rada of Ukraine "Recommendations of the Parliamentary Hearings on the topic: "On the State and Issues of Financing Education and Science in Ukraine" dated July 12, 2017, in 2015, the salary of the Doctor of Sciences (D.Sc./Dr. habil.), professor in Ukraine was \$134, while in the Czech Republic it is \$1,800, in Poland $-\$ 2,800$, and in China $-\$ 3,100$ respectively. Such low level of salaries of scientific and pedagogical employees does not exist in any country in the world [Resolution, 2017].

Ukrainian scholars have less and less pride in their own property, with neither means nor incentives to work. The educational and scientific sector is in a state of decline, which results in incorrectly defined priorities of the state's development.

The impact of the institutions on behaviour and incentives in real life is evident; they determine the further triumphs and defeats of nations [Acemoglu \& Robinson, 2012]. Inclusive institutions always invest in development and innovation, while looking for relevant approaches to provide the same benefits to the entire community in the future. It is important to note that sometimes waiting for dividends from such investments can take years. They are long lasting in their nature, since they aim to lay the foundations for high standards and proper 
social guarantees. Nations, which have crystallised awareness of the gradual change in the coordinated work of all components of transformation - economic or any other ones - tend to be among the leaders, dictating the world order.

\section{Domestic Political Institutions}

Political institutions of the country, which purpose is primarily to establish, execute, and support the authorities, can also be considered extractive. Comprehensive bureaucracy is quite objectively considered one of the main reasons for the slowdown of the Ukrainian political development. Under such conditions, the protection of own rights and freedoms, the restoration of social justice and the opportunity to initiate changes at both the state and local levels will become the prerogative of only the most patient citizens who are competent in law. These people will surely form a minority, and therefore will not be able to stand in the way of inactivity or a policy that does not meet national interests. Unlike inclusive institutions, extractive political institutions aim at retaining power for a long time in the hands of one group of stakeholders through informational propaganda in the media, low level of political literacy among the population, and minimising the influence of the opposition. Thus, the absence of any alternative allows controlling people for a long time. The relations between Ukraine and the EU in this context are the most significant factor.

Ukraine has been slowly approaching the Association Agreement with the EU for 7 years, since the first negotiations on the Agreement were initiated under the presidency of Viktor Yushchenko in 2007. Therefore, although at the beginning of the negotiations the EU officials insisted on signing an agreement on cooperation with the neighbouring country, it would be fair to regard this event as the basis of the current transformation of Ukraine through European integration.

Viktor Yushchenko during the presidency constantly complained about the corruption of the parliament, and entered the history of Ukraine more as a fighter for the restoration of the historical past of the nation and a talented beekeeper. Despite the fact that during the time of Yushchenko's presidency, the Holodomor of 1932-1933 was acknowledged as a genocide of the Ukrainian people, his participation in political strife before the eyes of the entire international community does not allow him to be identified with a strong political leader able to cope with his responsibility. The extension of the powers of the National Security and Defence Council in order to duplicate the powers of the Cabinet of Ministers in March 2005 is considered a vivid manifestation of the attempt to form extractive political institutions, since in this way Yushchenko tried to legitimately expand his power by increasing his influence. This caused heavy indignation in the parliament. The fuzzy position of the Government of Yulia Tymoshenko, the newly appointed head of the government, and her political party on the military aggression in Georgia in August 2008 on the part of the Russian Federation, gave rise to sharp criticism from the President during the meeting of the political council of the Our Ukraine party on September 20, 2008. The tensions between the President and Prime Minister of the country have become one of the prerequisites for the 2008 political crisis.

Thus, he did not introduce a visible improvement in the ordinary Ukrainians, and the promise to unite the national democratic forces for a joint further struggle remained unfulfilled.

Despite the manifested identification of Ukrainians with the European community, the emphasis was on understanding the whole nation as a whole, without any advances in the understanding of belonging to certain prevailing world coalitions, which is a fundamental 
component of the globalised world. Populism and the lack of political will of the head of state did not allow the development of political inclusive institutions.

Victor Yushchenko's successor — Viktor Yanukovych — who was the Prime Minister in the government of the "orange leader", has also not shown a great deal of political abilities and achievements. The closest political and business scope of people surrounding then-President of Ukraine Viktor Yanukovych and his son, Alexander, which was marked by the media as the "Yanukovych's Family", has become, in fact, the ruling elite in the country. According to Anders Aslund, Senior Researcher at the Institute for International Economics, business in Ukraine was represented by young entrepreneurs from Donetsk, friends of Alexander Yanukovych, who assumed all key economic positions in the government, as well as an important position of the Minister of the Interior.

The representatives of this clan purchased companies one after the other by illegal takeover. These purchases were described as non-voluntary ones, given that the "family" controlled the law enforcement agencies, the courts and the tax office. Later on, heavy industry, the media and banking were in their sphere of influence [Aslund, 2013].

The signing of the Agreement between Ukraine and Russia on the Black Sea Fleet in Ukraine, widely referred to as the Kharkiv Pact, with the President of the Russian Federation Dmitry Medvedev on April 21, 2010, according to which the Russian Federation Black Sea Fleet's Stay in Sevastopol was extended till 2042, was also a significant moment on the European route [Agreement, 2010].

At the same time, the establishment of a presidential-parliamentary form of government as a result of the Constitutional Takeover in October 2010 completely entrenched extractive institutions in the political life of Ukraine. Through legal concentration of the entire vertical of executive power in his own hands, Viktor Yanukovych established a dictatorship in the country and took a number of principal decisions even without prior public discussions.

Subsequently, the course on European integration gradually disappeared from the horizons of the Ukrainian future, while the former president found more and more rational reasons in joining the Customs Union, which members at that time, except for the Russian Federation, included only the Republic of Belarus and Kazakhstan. The beneficial gas contract with the Russians and the absence of any political ambitions of Viktor Yanukovych actually led to the imposition of pro-Russian values, the mediation of Ukraine in pursuit of the geopolitical goals of the Russian Federation. The desire to assimilate into the European community, to put into action its values and understanding of social justice, was perhaps the only factor behind the containment of growing social oppression and discontent.

The decision to suspend the process of preparing for the signing of the Association Agreement with the European Union on the grounds of the loss of a significant portion of the Russian market in this case and the banal lack of funds for the implementation of the Agreement became the apogee of dissatisfaction with Yanukovych's policy. Whereas the forceful opposition to the peaceful demonstrations and rallies on November 30, 2013, finally exhausted all patience of the Ukrainian nation, transforming the peaceful manifestations of the expression of will into the national liberation struggle against dictatorship, marked as the Revolution of Dignity.

As a result, the country achieved the removal of President Yanukovych from power, his dismissal from office, the dissolution of the government, more than a hundred dead and thousands of victims in protest actions, transformation of public consciousness. It was a lesson of political literacy, for which it was necessary to pay the price in blood. 
Hence, people had high expectations for the newly elected president Petro Poroshenko and his team in 2014. The Revolution of Dignity gave people an opportunity to conceive of themselves as the main factor in the existence of a state - people who have rights and are ready to defend them. For the first time in the history of Ukraine's independence, the reasoned criticism of power began to be taken into account. In fact, officials were forced to respond by communicating with the people on an equal footing, and not from the position of redundancy and supremacy, as it was before. So, even the positive effects of the policy of the current president - the signing of the Association Agreement, the visa-free regime with the member states of the European Union, the creation of the National Anti-Corruption Bureau of Ukraine, the reform of law enforcement agencies and the development of the European integration vector of Ukraine - disproportionately satisfies the population. The people pose to the head of the state a fair amount of requirements and questions regarding unfulfilled election promises. Despite attempts to level out the results of the actions of the previous government with clearly expressed extractive institutions in the form of lustration, the reformation of law enforcement agencies and the abolition of anti-people's decrees, the formation of political inclusive institutions is a distant prospect.

The bulky bureaucratic system continues to function. According to the results of the "Bureaucracy Index" survey for 2018, developed by the Institute of Economic and Social Studies (INESS), Ukrainian small businesses spend 469 person-hours a year on similar transactions. For example, the implementation of bureaucratic procedures in the Czech Republic is only 233 person-hours per year. The issues of corruption, mass migration abroad and the minor share of the middle class have been described above.

\section{Conclusion}

Ukraine is a state of enormous unrealised opportunities. Unfortunately, unrealised potential in the public consciousness is turning into a routine norm. The population, tired of constant political failures, loses confidence in the government, which level of public support was extremely low even in the best periods of Ukrainian statehood. Most conscientious citizens prefer to exist outside the formal system, trying not to participate in the life of society, first of all, looking for their own benefits in economic and political processes. As a result, the Ukrainian nation is fragmented, uncertain about tomorrow.

According to the author of the article, Ukraine is able to significantly accelerate the institutional transformation only under the following conditions:

1. Rational utilisation of the resource potential and abolition of the moratorium on the sale of agricultural land. Agriculture is one of the most investment-attractive sectors of the economy. This is due to the lack of fertile soils in some regions of the world in an era of climate change, as well as the insignificant cost of training specialists in the field. Therefore, by involving as many people as possible in farming, Ukraine will improve its investment attractiveness through attracting foreign capital, innovative technologies and advanced equipment. An existing moratorium on the sale of agricultural land is also a significant disadvantage of the modern land system — it must be abolished. Ukraine is one of the six countries on the planet, which does not have its own land market. Denis Nizalov, a consultant to the World Bank on Land Issues, in his paper notes that according to the World Bank, the budget loses more than UAH 1 billion each year due to the lack of funds from the land tax, understated rent for state and communal land, 
and also from the land that has no clear legal status [Nizalov, 2018]. Accordingly, as a result of suggested policy change, the country will become more open to globalisation, dictating its own conditions to attract foreigners.

2. Pursuit of a full-scale information fight against corruption. For unknown reasons, it is not accepted to talk about corruption in Ukrainian society. Combating this mysterious phenomenon is not mentioned in school and university curricula, and individual facultative measures are not able to overcome the systemic nature of the problem. Therefore, only mass broadcasting of the phenomena, manifestations and consequences of corruption in accessible forms will be able to educate generations of conscious citizens.

3. Introducing a fundamentally new type of social partnership between the authorities and the public. It is important to understand that an official of any level is just an elected representative, delegate from the people or a specific community. We should remember that every citizen, when paying taxes, has the right to control the quality of work performed by the people's representatives at all levels. Therefore, it would be advisable to register a personal cabinet of a citizen on the website of the Verkhovna Rada and local councils at the onset of adulthood, where s/he can review monthly reports on the work of all departments and analyse the adopted amendments or new bills. In such a way, it is also possible to collect signatures for petitions, provided that the approved decision will cause doubt or require revision. Accordingly, the principle of secret voting will be maintained, however the level of political awareness of the population will increase, because in order to take an active part in the political life of the country, it will not be necessary even to leave the house, not to mention the ballots and queues at the polling stations.

Objectively, there is always a possibility of radical changes. Moreover, the point of irreversibility in the form of the Association Agreement with the European Union became a reference point for the recent history of the creation of the Ukrainian state. Ukrainians realised that only the assertiveness, enormous efforts and steadfastness of the belief in institutional changes, backed up by the constant control of local self-government bodies and a high level of social responsibility, could give a positive impetus. The new course of decentralisation has also played a significant role in this. By creating numerous NGOs aimed at combating corruption, illuminating the illegal enrichment of officials in the media and helping the military, Ukrainian society has truly demonstrated the previously unprecedented ability to rally against common problems. At present, public activity is an integral part of the social and political life in Ukraine, creating the springboard for the self-fulfilment of people, who, because of extractive power structures, cannot get into the government to become agents of change. Taking into account all the analysed aspects and factors of influence, the forecast of the state development is considered positive, but only in the long-term perspective.

It is the subjective opinion of the author of the article that all further institutional transformations will be able to acquire the features not earlier than 10 years after the signing of the Association Agreement with the EU. This can be explained by the fact that Ukraine is dependent on macrofinancial assistance from the International Monetary Fund, and therefore, in order to receive the following tranches, the country will, first and the foremost, have to comply with the terms of this organisation. Accordingly, these adjustments to political and economic development may slow down somewhat.

Thus, given the prospects of the public sector in domestic institutions and the consequences of the destruction of outdated models during the Revolution of Dignity, Ukraine has prospects 
of growth as a country with decent democratic values and the proper realisation of economic potential. However, the promptness of these changes depends, at the first place, on the ultimate overthrow of the influence of extractive institutions.

\section{[Dd References}

Acemoglu, Daron, and James Robinson. Why Nations Fail. The Origins of Power, Prosperity and Poverty. New York: Crown, 2012.

Agreement between Ukraine and the Russian Federation on the Black Sea Fleet in the Territory of Ukraine. Document No. 643 _359 2153-VI dated 27/04/2010. http://zakon.rada.gov. ua/laws/show/643_359

Aslund, Anders. The Crisis in Ukraine: Yanukovych and the Oligarchs. BBC Ukrainian. December, 2013. https://www.bbc.com/ukrainian/politics/2013/12/131211_ yanukovych_tycoons_yg.shtml

Libanova, Ella, Liudmyla Cherenko and Olexander Vasiliev. The Population with Average Incomes as the Basis for the Formation of the Middle Class in Ukraine. National Security and Defense. Vol. 1, 2014: 79-96.

Malysh, Natalia. Structural Indicators and Economic Assessment of Natural Resource Potential. Public Administration: Theory and Practice. Vol.1, 2013: 1-7. http://irbisnbuv.gov.ua/cgi-bin/irbis_all/cgiirbis_64.exe

Nizalov, Denis. About the Cancer of the Ukrainian Economy, or How a Land Moratorium Harms Every Ukrainian. Economic truth. May, 2018. https://www.epravda.com.ua/rus/ publications/2018/05/10/636671/

Pestushko, Valeriy, Uvarova, Ganna, and Dovgan, Andriy. Geography: a Textbook for the Primary Education. Kyiv: Genesis, 2016.

Report of Bureaucracy Index. 2018a. How Many Hours Spends a Small Entrepreneur Dealing With Bureaucracy? http://bureaucracyindex.org/index/

Report of Country Ratings for GDP Per Capita (2017a). https:/www.imf.org/external/pubs/ $\mathrm{ft} / \mathrm{weo} / 2018 / 01 /$ weodata/

Report of Legatum for the Legatum Prosperity Index. Creating the Pathways from Poverty to Prosperity. 2017b. https://www.prosperity.com/rankings

Report of Pew Research Center for the American Middle Class. Stable In Size But Losing Ground Financially to Upper Income Families. 2018b. http://www.pewresearch.org/ fact-tank/2018/09/06/the-american-middle-class-is-stable-in-size-but-losing-groundfinancially-to-upper-income-families

Report of the Sovereign Tax Service of Ukraine. 2017c. https://dmsu.gov.ua/assets

Report of State Service of Geology and Mineral Resources of Ukraine. Fuel and Energy Raw

Materials. 2017d. http://geo.gov.ua/old/storinka/palyvno-energetychna-syrovyna

Report of State Service of Geology and Mineral Resources of Ukraine. 2017e. State of the Mineral Raw Material Base. http://geo.gov.ua/old

Report of the State Statistics Service of Ukraine. 2017f. http://www.ukrstat.gov.ua/operativ/ operativ2005/osv_rik/osv_u/vuz_u.html

Report of the Times Higher Education Foundation. 2018c. The Times World University Rankings. https://www.timeshighereducation.com/world-university-rankings

Report of Transparency International for Corruption Perceptions Index. 2017. https://www. transparency.org/news/feature/corruption 
Resolution of the Verkhovna Rada of Ukraine on "Recommendations of the Parliamentary Hearings on the topic: "On the Status and Problems of Financing Education and Science in Ukraine”. Document No. 2133-VIII dated 12.07.2017. http://zakon.rada. gov.ua/laws/show/2133-19

Explanatory Note to the Draft Law of Ukraine "On Amendments to Section VI "Final and Transitional Provisions" of the Budget Code of Ukraine. Document No. 8175 dated 21.03.2018. http://search.ligazakon.ua/1_doc2.nsf/link1/GH6B300A.html

Vasilyuk, Dmytro. The Development of the Middle Class in Ukraine from the Standpoint of a New Ideology of Its Functionality. Global and national problems of the economy. Mykolaiv. Vol. 8, 2015: 843-847. 